\title{
Politics of affect in Train to Pakistan and Tamas ${ }^{1}$
}

\begin{abstract}
Dipak Raj Joshi
Abstract

This paper analyzes selected Indian partition novels to unravel affective politics underlined in them. The major affects underlying in these novels are those of love, hatred, happiness, unhappiness, and outrage. One positive affect in favor of one concomitantly invites antonymic affect for the other. This refrain of affect, as this paper has tried to analyze, follows the nationalist historiographies of the writers like Khushwant Singh (The Train to Pakistan) and Bhisham Sahni (Tamas). The paper concludes that the affects evoked by the above mentioned novels are ethically tilted to the notions of community and nationhood of the respective writers-an ideologically biased orientation that results into a prose of demonization and denunciation of whom they consider the Other.
\end{abstract}

Key Words: Affective politics; Bhisham Sahni; Indian partition literature; Khushwant Singh; Nationalist historiography

This paper investigates briefly the Indian partition literature and the play of emotions in them, particularly in Khushwant Singh's Train to Pakistan and Bhisam Sahni's Tamas. Indian history was first written by Hindus, then by Muslims, and then by English. J. S. Mill, Edmund Burke, Hegel and so on were the historians whose historical line still forms the official nationalist historiography of India. Rituparna Roy (2010) has observed three strands of historical trajectories in India: the elite historiography of traditional nationalist discourse propounded by Nehru, the subaltern historiography developed by subaltern group writers, and the feminist perspective

\footnotetext{
${ }^{1}$ Cite this article as: Joshi, D.R. (2020). Contemporary Research: An Interdisciplinary Academic Journal, vol. 4 (1)

Dipak Raj Joshi, Associate Professor, Ghodaghodi Multiple Campus, Kailali; PhD Fellow at Tribhuvan University, Nepal Email: dipakrajoshi@gmail.com

Article history: Received on August 11; Accepted on October 23; Published on October 30

Peer reviewed under the authority of CRAIAJ, academic journal of Ghodaghodi Multiple Campus, Kailali, Nepal, with ISSN 2717-4611 (Print) and ISSN 2717-462X (Online).

(C) 2020 CRAIAJ
}

Full text of this article can be downloaded from www.craiaj.com and www.nepjol.info 
formed by feminist intellectuals and activists (p. 19). Against this background, this paper contributes to a more nuanced understanding of partition literature, revealing affective politics, through investigation of the play of emotions in them. Official history follows the path of mainstream nationalist historiography celebrating independence and the heroism of elite leaders. Elite political ideology is framed in nationalist history. Literature is rich in multiple perspectives.

There is a great deal of partition literature that helped forming partition historiography. Partition literature focuses more on unifying force of nationalism than on divisive force. Human tragedy caused by partition and its aftermath has been better represented by creative writers and artists, but here too, huge gap and silence. The writers are politically biased, favoring and disfavoring communities. The problem is that partition writers in English are much inclined to nationalist historiography line. Beerendra Pandey (2012) has postulated that partition literature written in English suffers from "cultural trauma" (p. 127), and hence is not good literature of trauma, "almost all Indian English partition novels written before 1984 . . . [follow] a configuration along the line of nationalist history ..." (p. 127).

In this context, I explore the politics of the affects of fear, shame, love, and hatred in the light of the theories of Sara Ahmed, Elspeth Probyn, and Brian Massumi. Efforts have also been made to examine contagious nature of affects in such literature, in the light of the theories propounded by Ben Anderson and Teressa Brennan as well. The aim is to understand the politics of their favoring and disfavoring of communities, their ethical tilt, and their moral denunciation to the communities.

The main goal of partition writing should have been to heal up the wound and reconcile the society. Shame is crucial for moral development, but this a far cry in nationalist historiography which demonizes the separatist Muslims. Indian nationalist historiography also blames imperialism for the cause of partition that planted the seeds of rivalry among communities. Intention of partition was to divide and rule and extend its regime. Partition literature has been interesting area for critics. The area has received considerable critical engagement. Roy has pointed out about Singh's writerly position in Train to Pakistan, the first novel ever written on the theme of partition and partition violence: "Singh himself was trained as a lawyer and practiced in Lahore High court till the partition took him away from his beloved city and landed him, like hundreds and thousands of other Sikhs and Hindus at the time, in Delhi" (p. 
33). Roy has emphasized the possible affective circumstances Singh might get influenced with, his being a lawyer, journalist, a Sikh, a victim and so on. Crane (2005) has also commented on Singh's novel to be like "sensational journalism" (p. 183) and "emasculating Hindus and Muslims" (p. 185).

Beerendra Pandey has cited Saros Cowasjee who has observed three patterns in Indian English partition fiction by the Sikhs: "one, the presence of Sikh protagonist, two, documentary authentication from newspaper reports, and three, the justification of Sikh brutality against the Muslims as counter-violence" (pp. 105-106). In addition to the patterns pointed out by Cowasjee, Pandey has investigated the fourth pattern about the representation of Sikhs in the partition violence, in Train to Pakistan: "a conscious foregrounding of Sikhs as civilized citizen vis-à-vis the barbaric Muslims through the configuration of the protagonist, Juggat Singh" (p. 106). Grishma M. Khobragade (2013) also reads Train to Pakistan as a novel having multicultural harmony "more than a powerful story of crime and horror" (p. 5). According to Khobragade, "partition has brought about division to the lives of people who dream of united India" (p. 4). He also points out the cause of partition to be the high politics.

Peter Morey (2000) has noticed "Indian nationalism as the main focus" (p. 163) in Train to Pakistan. The writers see British role in fostering communalism in Indian society. The literary texts are like "self contained account of Indian history" (p. 162). Morey further evaluates the texts like Train to Pakistan that are taken as "national allegory" (p. 162) and the versions of nationalist historiography are seen to be slightly changing after the death of Nehru. The critics have found that literature is crucial in releasing alternative versions of historiography. David Gilmartin (1998) has pointed out the cause of partition to be the "high politics" that is, "the negotiations between the British, the Congress and the Muslim League" (p. 1069). The high politics has been the main spice for the historians for a long time in writing about the partition. According to Gilmartin, "high politics of partition... [was] uninfluenced by the everyday politics of local lie" (p. 1069).

Although Indian partition writers claim to be writing without prejudice and biasness, not taking side, from the middle path, few critics have explored the line of nationalist historiography in them. Gyanendra Pandey (1992), Indian historian and the critic of nationalist historiography, writes about Hindu Muslim strife in India today and sees "real danger of reopening the old wounds" (p. 33), in partition literature. The 
nationalist historiography write about the criminal elements of both communities "filling the minds of the people with poisonous insanity" (p. 38). Gyanendra Pandey compares the strife in Tamas with the Jabalpur incident in 1961, Bhiwandi strife in 1970, Bhagulpur riot in 1989 and many other such riots. National historiography line has mentioned every such riot as criminalization of politics and communalization of national public life. History, journalism and film making focus on the activities of propagandists, criminal elements, local officials' dereliction from duty and long term economic changes as the cause of strife. Even the petty issues are given communal color by different interest groups. Economic causes of rivalries are described in the novels Tamas and Train to Pakistan. Fire in the grain market owned by Hindus, loot in the houses and shops in Tamas, and killing and loot in Train to Pakistan are described by Pandey as guided by economic interest: "Religion is no consideration among buyers and sellers. Profit is the overwhelming motif. They have vested interest in keeping the communal tension going." (p. 40)

Most of the observations made by critics about Indian partition literature are based on the theme of nationalism, historiography, subaltern, and women's issues. Some writers follow the line of nationalist narratives, whereas some others offer counter history. They claim of their objectivity but their claim gets proved irony when they replace one bias with another. In this way, I see Indian partition literature to be affective. It can be understood and investigated accordingly. Careful observation can lead anyone to ponder on partition literature: why the same event of partition is represented by different writers differently? Is it because the writers are writing from different 'affective circumstances' to target the audience with 'shared nervous system' or they are involved in giving ethical comfort to their respective community and bringing about moral denunciation of others? The argument constructed by the partition writers is seen as the play of affective politics.

Instead of depicting partition only in terms of political event and the theme of independence, Khuswant Singh's Train to Pakistan and Bhisham Sahni's Tamas both dig deep into local focus of partition violence. Singh (1969), in one of his interviews calls his novel to be "documentary" "sugar-coated with characters and a story" (p. 28). Himself a Sikh, Singh claims to have maintained objectivity and detachment with no animosity against either the Muslims or the Pakistanis (p. 28). Singh portrays terror stricken Muslims from the Sikh majority area whereas, Sahni portrays terrorstricken Hindu exodus from the Muslim majority area. Both of the novels have 
received considerable critical acclaim in India as well as abroad, and both have received India's prestigious national awards. In this paper, efforts have been made to investigate the affective politics of the authors in the texts.

In the fictitious town of Mano Majra, Sikhs and Muslims lived together in harmony before the partition, as described in Train to Pakistan. "All Mano Majrans venerate the local deity, the deo" (p. 7), Sikh guru Meet Singh and Muslim Mullah Imam Baksh are respected by both communities. There is mutual understanding among the villagers, which maintain the feeling of friendliness, peace, and non violence. Criminals and outsiders are blamed for everything that happened to the Muslims. Singh (1956) justifies the Sikhs' counter violence carefully attributing it to criminals and outsiders. In careful observation one can smell affective politics of the writer. Singh portrays Sikh heroism in Train to Pakistan through the character of Juggut Singh. The magistrate of the district Hukum Chand is portrayed as been compelled to evacuate the Muslims from the village since "there are mobs of twenty to thirty thousands of armed villagers... I have 50 policemen... and not one of them would fire a shot at a Sikh" (p. 150). Juggut Singh, who has criminal ancestry and who himself is "Jugga Badmas" in police record, the criminal and looter, is given the role of main character in the novel. Jugga is seen a passionate man of action, concerned for the safety of his beloved Nooran, the Mullah's daughter, when he knows of the conspiracy on the slaughter of Muslims by entrapping the train going to Pakistan. Jugga prevents the accident by cutting the rope meant for killing the Muslims. He himself is killed in the attempt, but succeeds in safeguarding the lives of the Muslims which police department fails to achieve. Thus even the Sikh with criminal background is portrayed to be the savior of the Muslims. This shows Singh's affective ethical tilt to his community.

Images like train full of dead bodies, corpses floating on the river, burial and burning of the corpses, loot and terror, well of death, husband killing wife and children evoke the atmosphere of fear and terror. Such images have strong affective power and are found in partition novels. The images spread horrific tales and rumors all over. In Train to Pakistan, such images contagiously affect all social actorsSikhs, Muslims, police. Rumors spread very fast. Police arrests Malli and his gang on the case of Lala Ram Lal's murder. The magistrate queries with the inspector in Train to Pakistan: 
'Who are Malli and his companion, Sikh or Muslim?' Asked Hukum Chand abruptly.

'All Sikhs.'

The magistrate relapsed into his thought once more. After some time he began to talk to himself. 'It would have been more convenient if they had been Mussulman. The knowledge of that and the agitator fellow being a Leaguer would have persuaded Mano Majra Sikhs to let their Muslims go! (pp. 94-95)

The police create the situation for evacuating the Muslims from the village by convicting Sultana and his gang to have involved in the murder of Ram Lal. The author tries to justify through the narrative that Sikhs didn't want to evacuate the Muslims or force them to leave, but they had to do it in order to send them to safe destination. The police spread rumors of atrocities being committed against Muslims all over, so that they might be ready to go to safe place. The problem of the district was not that Sikhs and Muslims are fighting, however the problem was they were not fighting and living together in harmony.

Train to Pakistan has become Singh's conscious effort to sweet-coat and clean cheat his own community blaming the other. Whatever the Sikh characters do in the novel is out of necessity. Even their evil acts are justified and given clean cheat. Jugga has liaison with Nooran and he impregnates her, but later he kills himself to safeguard her along with Muslim refugees to safety. Malli and his gang loot and capture the property and houses of the Muslims after their evacuation, but the act is very carefully justified in the novel. Muslim officer and the lambardar do not allow the Muslims to take all their belongings with them, and soldiers appoint Malli custodian of the Muslims' property (p. 128). But the narrator comments, "It was Malli with his five companions. With them were a few young refugees who were staying at the Sikh temple. None of them belonged to Mano Majra" (p. 130). Pakistan is blamed for whatever bad happens in the novel. Sultana and his gang, who were Muslims, are alleged for Ram Lal's murder. Police said Pakistan safeguards its Muslim criminals. Train loaded with dead bodies also came from Pakistan. Atrocities against the travelers on the train, armed people with spears all over - the sight that could be seen from inside the train, anecdote related to Sunder Singh and his family, for everything Pakistan and Pakistani Muslims are to be blamed (p. 169). Tewari and Ben-Ari's (2007) term can be used for this othering process as the forming of "conscience 
collective" (p. 32). Such type of othering images become widespread, ultimately adopted into mainstream narratives, and in the long run become images of hatred. Such type of formation can lead to hatred to Muslims and to Pakistan. Hukum Chand in Train to Pakistan blames Muslims:

Pakistani police and army took part in the killings. Not a soul left alive. Women killed their own children and jumped into wells... our Hindu women are like that: so pure that they would rather commit suicide than let a stranger touch them. We Hindus never raise our hands to strike women, but these Muslims have no respect for the weaker sex. (p. 22)

The magistrate who has dirty liaison with a Muslim girl, Haseena, almost his daughter's age, comments about Pakistanis that way. This is rather ironical. Hukum Chand blames Pakistani magistrates that they have evacuated Hindus from Pakistan and collected their properties and became millionaires overnight (p. 23). This comment helps readers forecast about Mano Majra Muslims' property under the greed of the police. Later, in the novel, it really happens. Malli and his men with the consent of the police evacuate and loot the property. Much effort of the author is seen to have invested on forming "conscience collective" about Pakistani Muslims and ultimately forming nationalist mainstream narrative based on hatred to the other. Singh, as a partition writer, does not appear impartial, as he has claimed to be objective, is seen to be tilted to his community, in Train to Pakistan. His biasness against (Pakistani) Muslims is psychologically propelled, as reaction formation of love towards secular India, which makes him turn away from the object of hatred that at the same time involves a turning towards home (India). This is where things become problematic for Singh and he negotiates this problem by being critical of Hindu hard liners like Hukum Chand and Lala Ram Lal in the novel.

Emasculation of not only the Muslims but also the Hindus in Train to Pakistan has challenged the notion of Hindu India. Hindu characters Lala Ram Lal and Hukum Chand are negatively represented. Ram Lal, the money lender, the only Hindu family in the village, has been portrayed greedy, mean, and obstinate. He refuses to handover keys of the safe to the robbers, rather chooses to be murdered. Hukum Chand is portrayed impotent, unable to consummate his liaison with the Muslim girl Haseena. He cannot safeguard the train carrying Mano Majra Muslims to Pakistan. He evades responsibility by releasing Jugga and Iqbal Singh from the prison in the hope that they will be able to prevent the massacre. Hukum Chand can be 
observed in the novel as the representative of Indian government, which was indecisive during the time of partition violence. Iqbal Singh also criticizes it, "get the bania government out" (p. 48), on order to get rid of princes and landlords. Other such characters like Banta Singh and Meet Singh express their discontent to the congress government and Gandhian nonviolence. For instance, Banta Singh says, "I was in the last war and fought in Mesopotamia and Gallipoli. We liked English officers. They were better than the Indians" (p. 48). Hukum Chand is not sure whether his orders will be carried out or not by the Sikh policemen. Earlier I have quoted Hukum saying "not one of them would fire a shot at a Sikh" (p. 150). So he justifies his decision about his evacuation of Muslims from the village. The writer's politics is to evoke Sikh community's dissatisfaction to the Congress government.

Muslims are also seen to be effeminized throughout the novel Train to Pakistan. Imam Baksh, the mullah of the mosque, is a weaver. Traditionally, "weavers are considered effeminate and cowardly. He is reduced to no more than a beggar. Most of the Muslims in the village are "weavers and potters" (p. 21). Muslim women are portrayed as singing, dancing, and sexually desirable. Muslims are the "tenants tilling land of the owners" (p. 21). So the Mano Majra Muslims are brothers to the Sikhs. How could the Sikhs evacuate and torture such friendly, timid, helpful Muslim mates from the village? Singh has obvious politics to bring the matter to the front. The novel is silent about the atrocities being committed by Hindus and the Sikhs. Singh only highlights the heinous acts of Muslims on the other side of the border.

Singh appears to be applying affective logic in the narrative to explain the Sikh uprising in the village. The refugees coming from Pakistan mould the Mano Majra Sikhs. They remind the villagers of the glory of their ancestry and of Sikhism. In Ben Anderson's term, "Morales" (p. 172), a motive force, guided by certain sentiment that can be very affective force for mobilizing the mass, can explain the context better. It transforms an "unimaginable heterogeneity... coalesce into an undifferentiated whole" (Anderson, p. 175). The young refugees mould the Mano Majra Sikhs in Train to Pakistan, thus:

'Is this a Sikh village?' he asked insolently...

'Yes, sir' answered the lambardar. 'It has always been a Sikh village.

We had Muslim tenants but they have gone.'

'What sort of Sikh are you?' asked the boy... 'Potent or impotent?'...

Full text of this article can be downloaded from www.craiaj.com and www.nepjol.info 
'Do you know how many trainloads of dead Sikhs and Hindus have come over? What are you doing about it? You just eat and sleep and you call yourselves Sikhs - the brave Sikhs! The martial class!' (p. 141)

The comment of this sort hits onto the basic identity of the Mano Majra Sikhs. In this way they coalesce with the refugees. Heterogeneous mass turns into homogeneity that their common goal becomes trapping the train at the bridge, and massacre the Muslims on it, so that they will be able to reply Pakistan with a gift train loaded with dead bodies and prove their Sikhism. And obviously, groups have heightened level of affectivity and lower level of intellectual functioning.

Harrison (1991) surveys the readership of the novel written in English in India during 1940s to be no more than $3 \%$ of the total population (p. 97). The educated, urban minority readership is ambivalent about acknowledging responsibility for the violence. "On the one hand there was tremendous love between Muslims and Hindus and Sikhs; on the other they killed each other with a savage hatred" (Harrison, p. 97). Singh in Train to Pakistan seems to be dishonest about the depiction of violence. He seems to be rather reluctant to acknowledge the atrocities from the side of Sikhs. He formulates the narrative so as to safeguard the Sikhs and blaming game to the Muslims. Train to Pakistan becomes "archive of affect" (Reiser, 2009: p. 77) to the readers forever and not only to the readers with "shared historical time" (Reiser, p. 77) that I have mentioned under Harrison's survey above. Singh writes from his own affective circumstances and he obviously has some affective politics to play. He makes his efforts to develop contagion of affect to the reader - sympathy to the Sikhs and hatred to the Pakistani Muslims. Singh establishes that Mano Majra Sikhs and Muslims lived together harmoniously exchanging "love for love" (Ahmed, 2004: p. 136), but the Muslim fanaticism from Pakistan spreads hatred and the subjects in the novel are depicted to use Ahmed's term, "attached to the other through hatred" (p. 50) because of the criminals and the outsiders from Pakistan. Nationalist historiography has serious problems in representing partition. It celebrates only the independence and the elite leaders, partition and subaltern uprising have been paid little attention. The analysis of Tamas in the next section posits further justification.

Tamas, an anecdotal novel, appears to be the collection of stories of suffering of individual Hindu and Sikh characters, in Muslim majority area, during partition violence. Harmony and love among different people in the beginning of the novel suddenly transforms into hatred and violence. The Congressmen- Hindu, Muslim, 
and Sikh - jointly take part in prabhat pheri, sweeping and cleaning the area, a sort of "symbolic act making residents aware of the need for civic sanitation" (p. 222). The rumor about the dead pig at the entrance of the mosque caused a sudden disappearance of love, peace, and harmony, leading to commotion. People changed suddenly. The old man with white beard loses his "conscious personality" (p. 10), using Freud's (1949) term, the story contagiously spreads all over creating a group motivated by affect, with the predominance of "unconscious personality" (ibid.) in them. When the mob is moved by some affects, it loses its conscience and responsibility. Some of the Congress activists had been Muslims but, in front of the mob they have to sacrifice their personal interest to the collective interest.

Sahni has tried to maintain unity in diversity. He portrays Hindus, Muslims, and Sikhs living together harmoniously, fighting against the English jointly, and making people aware of the self rule. "The member of deputation" (p. 246) jointly meet Richard, the representative of English government and the Deputy Commissioner of the district, to control the sudden outbreak of commotion, violent confrontation between communities caused by the incident of the dead pig at the entrance of the mosque. Lakshmi Narayan has great faith on Hayat Baksh (p. 253), Karim khan is sympathetic to Harnam Singh (p. 344), Shah Nawaj is very good friend to Lalaji, Raghunath and other Hindu characters (p. 304). Sahni describes love and harmony among people of different communities. He asserts that the communities fought against British rulers jointly as per the call of the independent leaders Gandhi, Jinnah, and Nehru. But Sahni is silent about why the leaders could not stop the sectarian communal violence. If Gandhi is responsible for independence, he could have stopped sectarian politics as well. How can he escape the issue simply by blaming English rulers? Readers smell Sahni's ideological tilt that he smells rat in Muslim League and English rulers for the cause of the partition violence in Tamas.

Sahni's creation of the character like Richard, the English officer, in Tamas further justifies that he is biased to the English. He depicts English officer to have lost his humanity. By reading his role in the narrative, readers develop hatred against him. Sahni justifies independence movement as nationalist mainstream narratives do. Sahni makes Richard speak: "'Listen, Liza', he said enthusiastically. 'I have to go to Sayedpur tomorrow, to get a disinfectant spread into a well in which many women and children jumped to their death. Why don't you come along too? It is a lovely drive ... What do you say? The entire area is very lovely!'” (p. 422). Even Richard's 
wife is portrayed to have been dissatisfied with the way he speaks. Even the horrible scene of the "well of death" (p. 406) cannot touch him. He develops the quality of "mental detachment" (p. 422), as a person in civil service. Person in civil service do not emotionally involve in every incident. His wife Liza responds: "Not even when a hundred and three villages are burnt down?' Richard paused a little and then said, 'Not even then. This is not my country, Liza, nor are these people my countrymen"' (p. 423). Sahni puts this English character into the frame of nationalist narrative and makes him speak like that. He has invested much effort in establishing to the reader that English rulers were indifferent to the people and their suffering. They were concerned only with their rule. Bakshi speaks in the novel thus: "they first bring about a riot and then quell it; they starve the people first and then give them bread; they render them homeless and then begin to provide shelter to them" (p. 417). In this way, Sahni is charged with the stand of the nationalist narratives that describe English rulers' making of propaganda, spreading of rumors, and the divide and rule policy. Karim Khan in Tamas also concludes:

'A ruler can see what you and I, ordinary folk, cannot see. The British ruler has all-seeing eyes, otherwise how can it be possible that a handful of firanghis coming from across the seven seas should rule over so big a country? The firanghis are very wise, very subtle, very far sighted...' (p. 272)

These all comments are deep rooted in Indian folk tales, history books, and text books. Sahni is affectively motivated from these nationalist narratives in carving the character of Richard in Tamas. The nationalist narratives function as "archive of affect" (p. 77), using Reiser's term, for the author, and of course for the audience with "shared nervous system" (Reiser, p. 125). In portraying the character of Richard, Sahni seems to be affected with nationalist narratives. The purpose behind the portrayal of Richard is to arouse readers' hatred to English rulers.

In Tamas, people are living together in harmony and brotherhood. They are fighting against the British. Suddenly with the outbreak of the riot, they start fighting with each other. The Muslims start burning houses and shops, and looting property of minority Hindus and Sikhs. Sahni very carefully blames the major portion of the violence to the other side, the Muslims. Violence by Muslim side is projected in a detailed, vivid, and outrageous way, whereas the violence by one side excluded or slightly mentioned to make the image of one side clean. In this way, in Sara Ahmed's term, the author is involved in making "love group" and "hate group" (p. 122). This is 
the conscious effort of the writer to defend the side he loves and blame the side he hates. It produces a differentiation between 'us' and 'them'. Sahni's narrative also shows Muslim community as more responsible for the atrocity than the others. This kind of practice ultimately fans up hatred in the group which the writer demonizes, and evokes a sense of revenge in them.

A critical look at the characters portrayed in Tamas can also help us study the formation of 'hate group' and 'love group'. Murad Ali, in the beginning of the narrative is portrayed as the initiator of the riot about dead pig at the entrance of the mosque. He orders Nathu to kill the pig (p. 177). This can be Sahni's attempt to show that Muslims are hated. They construct conspiracy, create propaganda, and spread rumor that lead to communal violence against minorities. Readers develop hatred to Muslims by reading it. Maulana Dad scolds Hakimji and Hayat Baksh saying "dogs of Hindus" (p. 256), provokes Muslims against Hindus and Sikhs. Rumors of killing, fire, looting by the Muslims to Hindus spread all over (p. 302). Characters like Shah Nawaz are depicted to have been helping Hindus to safe place who are in trouble. Behind his service, his evil intention is portrayed in the novel (p. 314). Shah Nawaz also managed to accumulate valuable things and jewelry in the pretext of service to humanity.

According to Freud, "groups have heightened affectivity and lower level of intellectual functioning (as cited in Brennan, 2004, p. 67). In such groups one automatically develops "herd instinct" (Brennan, p. 66). Another character Rajo in Tamas has also been depicted positively having purely humanistic attributes in her, but contagion nature of affect contaminates her too (p. 377). Rajo gives food and shelter to the only Sikh couple in the village, Harnam Singh and Banto (p. 375). Her husband Eshan Ali and her son Ramzan have been in the town with their fellow Muslims. As Eshan Ali enters the house with a "big black trunk" (p. 382), Sahni makes Eshan Ali's daughter- in-law, Akran, speak:

'Abba, you have brought a locked trunk. Heaven knows if there is anything worthwhile in it.'

'Why, it was so heavy, my back bent double carrying it. It is bound to be full of many things.'

'And it is only one trunk you have brought. Hasn't Ramzan brought anything?' (ibid.) 
Brennan's further postulation about the atmosphere "getting into the individual" (p. 36) can explain the situation better, what she calls the "outside in" (ibid.) model of transformation of affects. Outside environment affects everybody who encounters it. In communal politics everyone has his own communal ties and ethical tilt to it. Sahni also plays the affective politics by portraying others as negative and hated. Ahmed's postulation, "I love or hate them because they are like me or not like me" (p. 54) is seen to the affective act in the writer. Efforts have been made to bring moral denunciation of the Muslims.

Hindu and Sikh characters are much traumatized in Tamas. They are portrayed as victims, Muslims the perpetrators. The terror stricken only Sikh couple in the locality, Harnam Singh and Banto, loses their home and shop. Their son Iqbal Singh is traumatized by a Muslim mob. They force him for conversion into Islam (p. 391). His head was shaved, beard trimmed, the recitation of kalma, and the circumcision ceremony was performed (pp. 394-396). He is emasculated. Harnam Singh's daughter Jasbir Kaur jumped into the well, to escape the "Turks" (p. 406). In the same way, Lalaji and Raghunath's family faced many problems (p. 304). Sahni's politics can be said to develop readers' sympathy to Hindu and Sikh community, and hatred to the Muslims. When Sahni wrote this novel in 1970s, the readership of English novels had been increased to a considerable degree in comparison to the data about 1940s, as presented above. Besides, Indian writing had been read far and wide round the world. The words killers, marauders, Turks, Muzahids, terrorist etc., used to represent Muslims in the novel became quite significant to the Western readers when the West has labeled Islam as the threat world-wide after September 11 incident in America. Such manner of labeling Muslims as killers is termed as "hate crime" (p. 40) in the words of Perry (2001). Such branding process to a particular community into "hate group" can be a source of social unrest.

Sahni depicts Muslims as sweepers, shoemakers, tailors and so on. Some Muslims like Shah Nawaz are depicted as big traders though (p. 305). Majority of Congress activists are Hindus. They are grain market dealers, land owners and so on. Sahni comments about the causes of communal rivalry, "the warriors had their feet in the twentieth century while their minds were in the medieval times" (p. 397). He refers to the Muslim invasion to India in the medieval times. He is silent about the class distinction prevalent in society as the cause of social unrest. He blames Muslims for the communal tension, their collective unconscious formed from the distant past. 
We can make note of the economic causes of antagonism. The "fire in the grain market" (p. 294), in Tamas, also suggests that the agitated Muslims attacked the grain market, the economic stronghold of the Hindu merchants. Looting and fire in the houses and shops has nothing to do with the dead pig at the entrance of the mosque. Class tension and profit motif that have been accumulated in their collective unconscious got released during the tension. Hindus are in stronghold of congress politics. Since politics controls every socio-economic activity and Muslims are not well represented in Congress politics, the voices of dissatisfaction are seeking outlet. But Sahni is not highlighting these things in the novel. He is again affectively motivated by the mainstream elite historiography, in depicting partition violence.

Partition violence was India's horrible past. The goal of partition writing should have been to help heal up the wound and reconcile the society. Writing shame and writing of stories of optimism and hope can only heal the trauma deep rooted in Indian psyche. Singh and Sahni move one step ahead from nationalist historiography of India in depicting common people's plight during partition. They portray harmonious relationship among communities before partition and wish for the continuation of the same in the future. They blame outside force for the spread of hatred against the communities. But the problem is that each writer writes from his affective circumstances. Their effort is seen to prove clean cheat to their respective community. They are not ready to accept the guilt. Rather they blame the other. They claim of their objectivity but it becomes irony. The partition writers seem to be affectively motivated. Both Singh and Sahni follow the nationalist historiography line. Both blame English rulers and Muslims for the cause of partition violence.

To conclude, Sahni advocates secularism that had also been the nationalist policy when he wrote Tamas. For that he depicts multicultural love, and efforts have been made to establish "the integration of difference or in the imperative to mix" (Ahmed, p. 139) between the communities. However, Muslim (Pakistani) fanaticism contagiously contaminates the secular practice and multicultural love in Indian society. Pakistani Muslim fanaticism affected Muslim community in India that developed their intense hatred against Hindus and the Sikhs. Sahni seems to be establishing this argument in Tamas. Khuswant Singh in the same way, in Train to Pakistan, portrays ideal love between communities where, "love comes into being as a form of reciprocity" (Ahmed, p. 130) but the outsiders and the criminals from Pakistan succeed in filling Sikh youths' mind with intense hatred against Pakistani 
Muslims. Both of the writers seek to heal up the trauma of partition but Pakistani Muslims' fanaticism has been depicted as the factor of hindrance. When Singh and Sahni wrote their novels there had been intense anti Pakistani sentiment in the nationalist narratives. By writing novels on the theme of partition both of the writers play the affective politics of love and hatred.

A composite, secular Indian society evokes good feelings for Sahni which point towards the affect of happiness that he wants to evoke in his readers. Happiness is a condition that is laboriously cultivated and furiously defended. The affect of happiness puts the Indians in general, and the Hindu and Sikh survivors of partition violence into negotiating contact with the trauma of 1947. It must not be forgotten that what is appropriate to increase pleasure also diminishes pain in us at the same time. To be affected by something is to evaluate that thing, and when Sahni evaluates in Tamas, the partition trauma of 1947, he makes his own body and the bodies of his Indian readers turn toward the political development that caused the dismembering of British India. Affect is contagious, that is bodies can catch feelings as easily as catch fire. So, if Sahni evokes positive affect for secular India, he conversely creates a negative affect towards Muslim communalism which he associates with the practices of the Muslim League. The bad feelings that he creates for Muslim communalism are oriented toward relapse into medieval thinking, as a kind of stubbornness that comes in the way of progressive modernity. Similarly the good feelings that he evokes for secular India are associated in Tamas with moving up and getting out. Khuswant Singh, likewise, in Train to Pakistan, does similar things but the affects of negativity towards Pakistan and that of positivity for secular India are more overt there. As a result, the politics of love and hatred are quite explicit there. In Tamas, it remains rather implicit. Partition literature has been fertile ground for the investigation of affective politics. Pakistani partition literature, on partition and independence, in this context, seems to be interesting area worth exploring, for the investigation of alternative perspective to the Indian one.

\section{Acknowledgements}

University Grants Commission Nepal has been sincerely acknowledged for the PhD Fellowship award. My PhD Supervisor Chair Professor Dr. Beerendra Pandey's insightful and encouraging support has also been acknowledged. 


\section{References}

Ahmed, S. (2004). The cultural politics of emotion. Edinburgh: Edinburgh University Press.

Anderson, B. (2007). Modulating the access of affect: Morale in the state of total war. The affect theory reader. Eds. Gregg, M. and Gregory J. S. Durham: Duke University Press, pp. 161-185.

Brennan, T. (2004). The transmission of affect. Ithaca: Cornell University Press.

Crane, R. J. (2005). Inscribing a Sikh India: An alternative reading of Khuswant Singh's Train to Pakistan. Eds. Morey, P. and Alex T. Alternative Indias : Writing, nation and communalism. New York: Rodopi, pp. 181-196.

Freud, S. (1949). Trans. James Strachey. Group psychology and the analysis of the ego. London: Lowe Brydone Printers Ltd.

Gilmartin, D. (Nov. 1998). Partition, Pakistan, and South Asian history: In search of a narrative. The Journal of Asian Studies (54-4). Association for Asian Studies, pp. 1068-1095. <http://www.jstor.org/stable/2659304>.

Harrison, F. (Sept.-Oct. 1991). Literary representation: Partition in Indian and Pakistani novels in English. Indian Literature (34-5). Sahitya Academy, pp 94-110. <http://www.jstor.org/stable/23336961>.

Khobragade, G. M. (March 2013). Reflection of multiculturalism in Khuswant Singh's Train to Pakistan. Galaxy: International Multidisciplinary Research Journal (2.2), pp. 1-6.

Massumi, B. (2007). The future birth of affective fact: The political ontology of threat. The affect theory reader. Eds. Gregg, M. and Gregory J. S. Durham: Duke University Press, pp. 52-70.

Morey, P. (2000). Functions of India: Narrative and power. Edinburgh: Edindurgh University Press.

Pandey, B. (2012). Historiography of partition. New Delhi: The Study Publication.

Pandey, G. (Winter 1992). In defense of the fragment: Writing about Hindu Muslim riots in India today. Representations (37). University of California Press, pp. 27-55. <http://www.jstor.org/stable/2928653>.

Perry, B. (2001). In the name of hate: Understanding hate crimes. New York: Routeledge.

Reiser, J. (2009). Trauma, 9/11, and the limits of affective materialism. An Unpublished PhD Dissertation. John Hopkins University.

Full text of this article can be downloaded from www.craiaj.com and www.nepjol.info 
Roy, R. (2010). South Asian partition fiction in English: From Khuswant Singh to Amitabh Ghosh. Amsterdam: Amsterdam University Press.

Sahni, B. (2002). Tamas (published in 1974). Printed in Memories of madness: Stories of 1947. New Delhi: Penguin Books, pp.173-456.

Singh, K. (2002). A train to Pakistan (published in 1954). Printed in Memories of madness: Stories of 1947. New Delhi: Penguin Books, pp. 1-172.

. . (1969). Interview with Khuswant Singh. Mahfil 5.1/2, pp. 27-42. Michigan State University, Asian Studies Centre. <http://www.jstor.org/stable/40874210>.

Tewari, S. and Ben-Ari, E. (2007). The partition motif: Concepts, comparisons, considerations. The partition motif in contemporary conflict. Eds. Tewary and Ben-Ari. New Delhi: Sage Publications, pp. 19-54. 